\title{
The Development of Multiple Intelligence Based Textbook
}

\author{
Suwanto ${ }^{1 *}$, Azrina Purba ${ }^{2}$ \\ ${ }^{1}$ Department of Mathematics Education, STKIP Asy-Syafi'iyah Internasional Medan, Sumatera Utara, Indonesia, 20142 \\ ${ }^{2}$ Department of Science Education, STKIP Al-Maksum Langkat, Sumatera Utara, Indonesia, 20814 \\ ${ }^{*}$ Coresponding author: suwantompd89@gmail.com I Phone Number: +6285371286605
}

\section{ARTICLE HISTORY}

Received: 13 January 2021

Revised: 18 March 2021

Accepted: 16 April 2021

KEYWORDS

Develop Textbooks;

Multiple Intelligence;

Equations; Inequalities;

\begin{abstract}
This study aims to develop multiple intelligence-based textbooks seventh grade junior high school students with material on equations and inequalities. It is hoped that the results of the development of this textbook can improve student learning outcomes, especially in the ability of mathematical representation. The population used was students of SMP/MTs in Medan, by taking several research samples 108 students. The development model of this textbook uses the 4D development model (define, design, development,Dissemination), but due to the situation during Covid 19 and time constraints it only reaches the development of the expert validation section and limited trials. Thus in this development it only comes to the analysis of validation and practicality of textbooks, but for effectiveness will be continued in next research. The analysis shows that multiple intelligence-based textbooks on equations and inequalities in class VII are declared valid and practical.
\end{abstract}

\section{INTRODUCTION}

One of the algebraic materials that is very important for students to understand is the One Variable Linear material (Nafii, 2017). But in practice, there are still many students who fail to understand this material, learning does not connect real life with learning activities in class. Even though students are required to be able to solve problems in their lives as a consequence that they have learned mathematics. The failure to solve math problems is because students make mistakes in mathematical concepts, principles and operations (Jumiati \& Zanthy, 2020). Besides, the approach taken by mathematics teachers is less varied (Fitriani \& Maulana, 2016; Murdiyani, 2012). Then teacher-centered learning, teachers are more active in learning, another cause is not linking the real life of students with the material being taught (Muslimin et al., 2012). It cannot be denied that this shows the quality of learning carried out by the teacher.

Besides the teacher, Mulyasa (in Suwarni, 2015) stated that one of the factors that caused the low quality of learning, among others, had not been utilized optimally by both teachers and students of learning resources, like a texsbooks (Budiningsih et al., 2015). The existence of textbooks is very important, without textbooks both teachers and students will find it difficult to increase the effectiveness of learning (Sadjati, 2012; Sholeh, 2013). According to Nawawi (Jailani, 2017) learning resources are anything that can be used as a place where teaching materials are available or where someone is learning from.

Although the textbooks or textbooks used in schools have met national standards, according to his observations there are still many shortcomings to support students to learn, because it is not in accordance with student characteristics (Anggela et al., 2013; Sukerni, 2014; Suwarni, 2015) and student needs (Su'udiah et al., 2016). There are very few textbooks in circulation that consider mathematical abilities such as students' mathematical representation abilities. Representation aims to make it easier for students to solve mathematical problems which are abstract in nature to become more concrete for students (Yazid, 2012). Students must have the ability to represent and articulate and reflect the same problem in different ways or views, into mathematical symbols. Even though the ability of representation is a new ability compared to the four abilities defined by NCTM (NCTM, 2000), representation needs serious attention (Abdullah, 2012).

Several previous studies, such as (Usmadi, 2020; Samsuriadi \& Imron, 2019; Putriani \& Rahayu, 2018; Ridhollah et al, 2021; Sarah et al, 2021) found that learning models greatly affect students' ability to learn mathematics. This is in line with research (Paroqi et al, 2020; Yarmasi et al, 2020; Maulidawati et al, 2020; and Fonna \& Mursalin, 2019) that the learning process that occurs in the classroom is also strongly influenced by the model used by the teacher when conditioning students in learning mathematics. Along with the development of strategies, models, and methods of teaching teachers in learning theory where mathematics is one of the objects that receive the benefits of the new model. This is because mathematics is one of the subjects that need attention from research in the field of education.

Thus, it is necessary to design student textbooks, especially in mathematics learning that focuses on students' mathematical representation abilities. Certainly not an ordinary textbook, textbooks that are considered to be able to improve students' mathematical representation abilities are textbooks that are developed involving the intelligence possessed by students. Learning that involves all multiple 
intelligences can improve students' mathematical representation abilities (Suwanto, 2018). The purpose of this development research is to answer whether textbooks based on multiple intelligence can be said to be valid and practical in improving the mathematical representation abilities of junior high school students.

\subsection{Textbooks and their Role in Learning}

Textbooks are all forms of material used to assist teachers/instructors in carrying out teaching and learning activities. The material in question can be in the form of written material or unwritten material (Lestari, 2018; Majid, 2011). Textbooks allow students to learn a basic competency or competency in a coherent and systematic manner so that they can accumulate all competencies in a comprehensive and integrated manner (Darmadi, 2012). In detail, the types of learning materials consist of knowledge (facts, concepts, principles, procedures), skills, and attitudes or values.

Textbooks are very important for teachers and students in the learning process. Without textbooks it will be difficult for teachers to increase the effectiveness of learning. Likewise with students, without textbooks it will be difficult to adjust to learning, especially if the teacher teaches the material quickly and unclearly. Therefore, textbooks are considered a material that can be used by both teachers and students as an effort to improve the quality of learning. The role of textbooks for teachers includes (1) saving time, (2) changing the role of the teacher as a facilitator, and (3) the learning process is more effective and interactive.

\subsection{Multiple Intelligence}

Multiple intelligences are various skills and talents that students have to solve various problems in learning. The originator of the theory of multiple intelligence is Gardner, in 1983 in Gardner's research it only found seven multiple intelligences including; (1) musical intelligence, (2) bodily kinesthetic intelligence, (3) mathematical logical intelligence, (4) linguistic intelligence, (5) spatial ability, (6) interpersonal skills and (7) intrapersonal abilities. But over time he added naturalistic intelligence as the 8th multiple intelligence (Yaumi, 2012).

Its application in the 2013 curriculum, student multiple intelligence can be developed through core competencies, scientific approaches and an authentic assessment system (Machali, 2014). However, in implementation, multiple intelligence has not been implemented evenly, it still focuses on mathematical logical intelligence and verbal intelligence only (Jasmine, 2007). Even though naturalistic intelligence has a positive correlation to mathematical literacy (Setiawan, 2019).

\section{METHOD}

To see its validity, it involves experts in mathematics, language, and design. Furthermore, for practicality and effectiveness, it will involve teachers and grade VII students who come from SMP/MTs and equivalent schools in the city of Medan. Each school will randomly select one class as a sample for a limited trial. The research was conducted from January to December 2020.

This type of study is Research and Development (R\&D) using the 4-D by Thiagarajan in 1974 which has been modified into a 3-D development model which consists of three stages: (1) Define, (2) designing and (3) Development.
Validation Analysis

Determine the validation of the Khabibah (in Prasetyo, 2012) with formulas

a. Average of each criterion:

$$
K_{i}=\frac{\sum_{h=1}^{n} V_{h i}}{m}
$$

$\mathrm{A}_{\mathrm{i}}=\frac{\sum_{j=1}^{n} K_{i j}}{m}$

b. Average total validity (RTV)

$$
\mathrm{RTV}=\frac{\sum_{\mathrm{i}=1}^{\mathrm{n}} A_{\mathrm{i}}}{\mathrm{n}}
$$

c. Criteria Average total validity (RTV):

$$
\begin{aligned}
& 4 \leq \mathrm{RTV} \leq 5 \text { very valid } \\
& 3 \leq \mathrm{RTV}<4 \text { valid } \\
& 2 \leq \mathrm{RTV}<3 \text { less valid }
\end{aligned}
$$

$1 \leq \mathrm{RTV}<2$ not valid

d. Revision of textbooks is carried out according to input from the validator so that a valid textbook is obtained.

\section{Practical Analysis}

Seeing the practicality of textbooks can be viewed from student activities and student responses (Irsalina \& Dwiningsih, 2018)

Respons $=\frac{\text { Total positive response }}{\text { Total response }} \times 100 \%$

Textbook practicality criteria:

$0-20 \quad$ not practical

$21-40 \quad$ less practical

41-60 pretty practical

61-80 Practical

$81-100 \quad$ Very practical

\section{RESULTS AND DISCUSSION}

\subsection{Define}

\section{Preliminary-Final Analysis}

This initial and final activity is carried out by analyzing mathematics at grade VII junior high school which is in accordance with learning theory and matters relating to multiple intelligence as well as the abilities of students expected based on the applicable curriculum, the following is a description of the preliminary analysis with various literatures.

Mathematics subject matter given to class VII students are sets, numbers, lines and angles, squares and triangles, comparisons and scales, equations and inequalities, arithmetic, transformations, statistics, and odds (Kemendikbud, 2013; Tasari, 2011; Wagiyo et al., 2008). Among these materials the researcher wants to focus on the material of linear equations and inequalities of one variable. In connection with this material, the basic competence of one variable linear equations and inequalities is explaining the linear equations and inequalities of one variable and their solutions and solving problems related to the linear equations and inequalities of one variable.

To make it easier for educators to deliver material on linear equations and inequalities supported by teaching materials, but the teaching materials used so far do not pay attention to the diversity of students (Latifah \& Widjajanti, 2017). Multiple intelligence-based texsbooks are a learning tool that supports the effectiveness of multiple intelligencebased learning. Learning theory that supports multiple intelligence-based learning is humanistic learning theory. In humanistic learning theory, learning is considered successful 
if the student understands his environment and himself. Students in the learning process must try with their abilities so that they are able to achieve self-actualization as well as possible. The application of humanistic learning theory according to Kolb's view consists of four stages; (1) concrete experience; (2) active and reflective experience; (3) Conceptualization; (4) active experimentation (Aradea \& Harapan, 2019; Perni, 2019).

This learning theory focuses on the potential of humans to seek and discover the abilities they have and develop these abilities (Qodir, 2017). Social interpersonal skills and methods for self-development aimed at enriching oneself, enjoying life and also society. The ability to build yourself positively is very important in education because of its association with academic success. By knowing the potential and intelligence it has, of course, will give confidence to students to develop this potential and intelligence. The consequence of freeing students to develop themselves, educators who act as facilitators must design learning according to the needs, potentials and intelligence of the students. Educators cannot impose their will in providing material that is unwelcome and irrelevant to the background of students.

\section{Student Analysis}

Student analysis is to find data on student characteristics, in terms of student abilities, student social conditions, learning styles and student multiple intelligence, by knowing student learning styles and multiple intelligence, educators can determine the appropriate treatment (Andayani Mirda et al., 2018; Şener \& Çokçalışkan, 2018). The following are the student characteristics data obtained.

Table 1. Student characteristics

\begin{tabular}{lcl}
\hline \multicolumn{2}{c}{ Student characteristics } & \multicolumn{1}{c}{ explanation } \\
\hline \multirow{2}{*}{ Gender } & Male & $41,67 \%$ \\
\cline { 2 - 3 } & Female & $58,33 \%$ \\
\hline Studen ability & Mathematic & Enaugh \\
\cline { 2 - 3 } & Genarap & Good \\
\hline
\end{tabular}

Parents' educational background

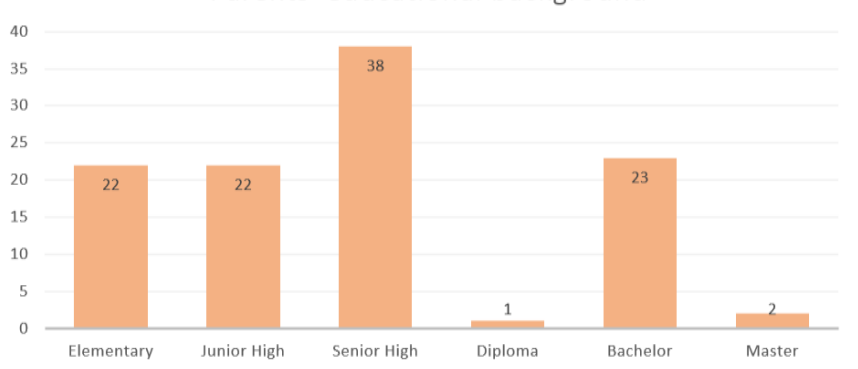

Figure 1. Parents' educational background

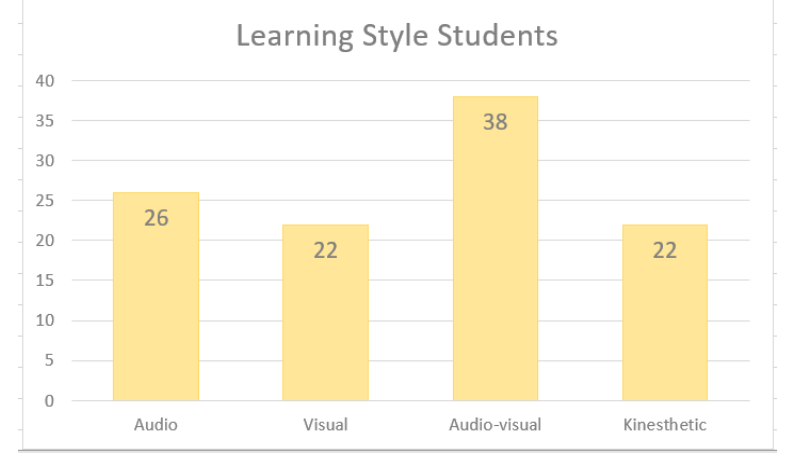

Figure 2. Style learning
Multiple Intelligence Students

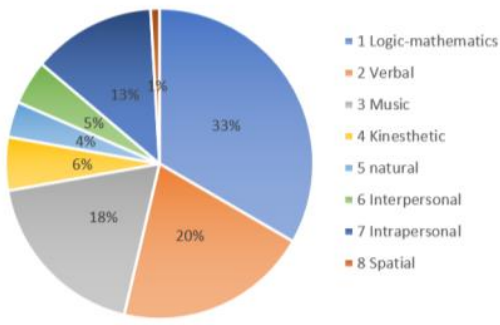

Figure 3. Multiple Intelligence students

\section{Concept Analysis}

Multiple intelligences or commonly referred to as multiple intelligences are the various skills and talents students have to solve various problems in learning (Kandeel, 2016). Every individual has a set of abilities that are brought to be able to solve the problems it faces and how to create useful results. Multiple intelligences-based learning takes advantage of the dominant intelligences possessed by students to improve other abilities and can help students more easily understand material in mathematics (Rofiah, 2016)). The concept of multiple intelligences that focuses on the realm of uniqueness always finds the uniqueness of each child (Kusniawati, 2016). With the uniqueness of their students, they have different ways and needs in learning. Multiple intelligences-based teaching materials in learning seek to involve the uniqueness of student intelligence in every learning activity (Husamah et al., 2557; Ilyas, 2019; Latifah \& Widjajanti, 2017).

\section{Task Analysis}

The ability to represent mathematics is an indispensable ability in understanding linear equations and inequalities (Graciella \& Suwangsih, 2016; Sulastri et al., 2017). Mathematical representation ability is one of the process skills related to the ability of students to present reports, ideas, and ideas (Yuniawatika, 2011). Representation is defined as a configuration of characters, pictures, concrete objects, etc. which can symbolize or represent something else (Sajadi et al., 2013). In other words, representation is a configuration of form or arrangement) which can describe, represent, or symbolize something in a way.

The basic competencies related to the material of linear equations and inequalities are 3.8 explain the linear equations and inequalities of one variable and 4.8 their solutions and solve problems related to the linear equations and inequalities of one variable. Based on these basic competencies, the learning activities carried out can be in the form of;

Observing everyday problems related to linear one variable equations.

Collect information on solving linear equations and inequalities of one variable through algebraic manipulation to determine the simplest form.

Presenting the results of learning about one-variable linear equations, the equivalent form of one-variable linear equations, and the concept of inequality.

- Solve problems about linear equations and inequalities of one variable.

\subsection{Design}

The selection of material or delivery media will be adjusted to the multiple intelligence of students, for example word processing for verbal intelligence; visualize explanatory material for visual intelligence; guessing the number of certain sounds for musical intelligence; direct practice for 
kinesthetic intelligence; group learning and discussion for interpersonal intelligence; and others. Of course, another consideration is to raise activities related to their daily lives, such as buying snacks in the canteen, activities at school and so on. On the other hand, the selection of learning resources is easily obtained from their surroundings.

In order to differentiate this textbook from other textbooks, the theme of multiple intelligence was raised, as shown below. Coloring is also very much considered in the design of this books. This is because it attracts students to look at this book in the hope that they are stuck reading. at their age color can affect their memory (Sujarwo \& Oktaviana, 2017). Remembering that at this age students still like something colorful (Ningtyas et al., 2014).

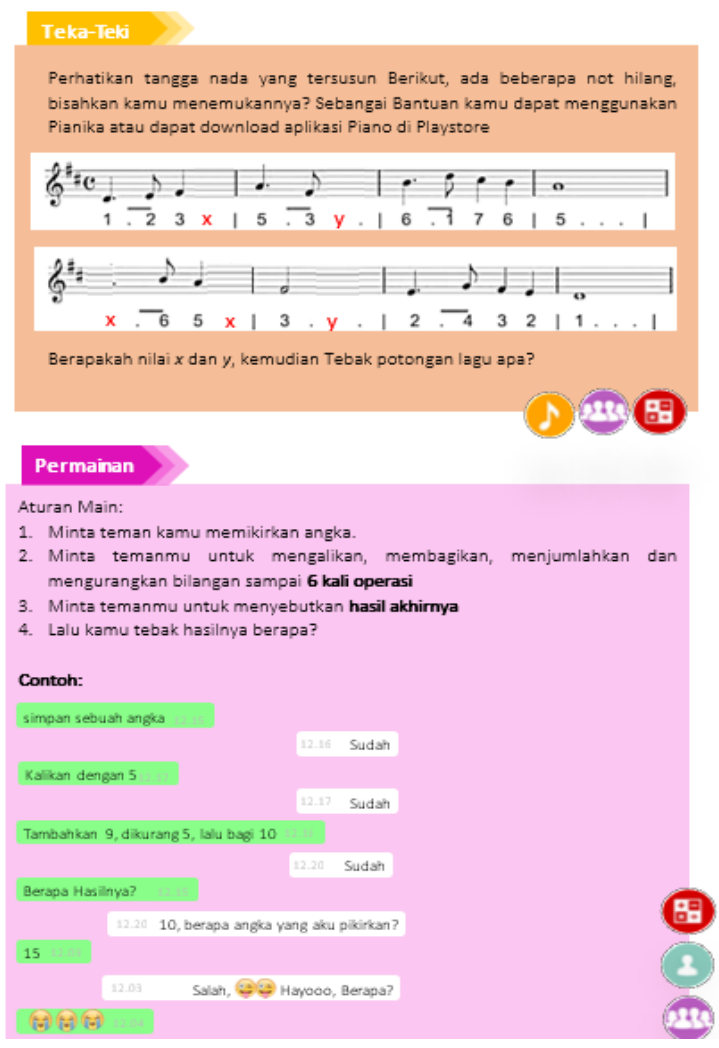

Figure 4. Textbook Design

In Figure 4, in the puzzle section, the bottom box contains what intelligence symbols can participate in solving the puzzle. then in this book an exercise is also made in which the exercise is like the appearance of social media conversations. this appearance is due to their very close relationship with social media. It is hoped that all these displays will attract their attention to solve the exercise and the problems raised. Then for the presentation or design of the teaching materials used it is also adjusted to multiple intelligence, but in general the designs displayed have the theme of multiple intelligence. For certain conditions, the theme is matched with identical exposure, such as natural intelligence is stronger to green, intrapersonal intelligence is identified as purple and so on. However, the choice of design, font size and format still takes into account the mathematics.

\subsection{Development}

\section{Validation}

The development stage is the stage for producing a development product which is carried out in two steps, namely: (1) expert appraisal followed by revision, (2) developmental testing. The purpose of this development stage is to produce the final form of teaching instruments and materials after going through revisions based on input from experts/practitioners and experimental data. In this study, only up to the expert's judgment, given the limited time and conditions that made it impossible to conduct development trials.

Expert validation is an expert assessment of teaching instruments and materials including: Design, language, content appropriateness and presentation components (Soeyono, 2014). This expert validation is to gather information about suggestions and assessments of teaching materials (Gazali, 2016). Based on input from experts, the instruments and teaching materials were revised to make them more precise, effective, easy to use, and of high technical quality. Expert validation consists of five experts consisting of design, language and content experts. After the evaluation was carried out by the validators, revisions and improvements were made based on the requests requested by the validators. Furthermore, the validators are re-evaluated until there are no more improvements from them so that it will produce teaching materials that are no longer mistakes in terms of content, writing, delivery and others. The results of expert validation are as Table 2.

Table 2. Result of Design Validation

\begin{tabular}{lll}
\hline Components & Sub-Components & Score \\
\hline Size & Size & 4,3 \\
\hline Cover Layout & Posisiton & 3,9 \\
\hline & Typography & 4,1 \\
\hline Content Layout & Ilustration & 4,2 \\
\hline & Posisiton & 4,1 \\
\hline & Typography & 4,0 \\
\hline & Ilustration & 3,8 \\
\hline
\end{tabular}

Table 3. Result of Content Feasibility Validation

\begin{tabular}{lll}
\hline Components & Sub-Componens & Score \\
\hline Dimension of Spritual Attitude & & 3,5 \\
\hline Dimension of Social Attitude & & 3,9 \\
\hline Dimension of knowledge & Object scope & 4,1 \\
\cline { 2 - 3 } & Object accurate & 4,1 \\
\cline { 2 - 3 } & Rule of low & 3,9 \\
\hline Dimension if skiil & & 4,5 \\
\hline
\end{tabular}

Table 4. Result of Presentation Components validation

\begin{tabular}{ll}
\hline Components & Score \\
\hline Presentation Techniques & 3,6 \\
\hline Presentation support & 3,8 \\
\hline Presentation of learning & 3,5 \\
\hline Completeness of presentasion & 3,9 \\
\hline
\end{tabular}

Table 5. Result of Language Validation

\begin{tabular}{ll}
\hline Components & Score \\
\hline Unadornet & 3,5 \\
\hline Communicative & 3,6 \\
\hline Dialogical and Interactive & 3,7 \\
\hline Suitability with the level of development of students & 3,7 \\
\hline Cluster and coherence of thought lines & 3,5 \\
\hline Use of Symbols and Terms & 4,1 \\
\hline
\end{tabular}

\section{Practicality}

The next stage is to determine the level of practicality, the level of practicality seen from the student assessment sheets and teacher assessment sheets (Nurmita, 2017). The results of the questionnaire on the student assessment sheet obtained 90.57 in the very practical category, while for the results of the teacher assessment questionnaire it was obtained 85.6 with the practical category. Besides it can be concluded that multiple intelligence-based textbooks are 
declared practical. The results of the teacher assessment questionnaire and student assessment questionnaire can be seen in the Table 6.

Table 6. Teacher's Response to Textbooks

\begin{tabular}{|c|c|}
\hline Assessment Aspects & Score \\
\hline Content suitability & 3.97 \\
\hline Suitability with student development & 4.33 \\
\hline Presentation & 4.37 \\
\hline Langauage & 4.17 \\
\hline Effectiveness of Use & 4.57 \\
\hline & 4.28 \\
\hline
\end{tabular}

Table 7. Student Responses to Textbooks

\begin{tabular}{lll}
\hline \multicolumn{1}{c}{ Aspects } & \multicolumn{1}{c}{ Indicator } & Score \\
\hline Suitability of use of \\
language and sentences & Simplicity of Language & 4.6 \\
\cline { 2 - 3 } & Clarity of Sentences & 4.7 \\
\cline { 2 - 3 } & Suitability Display & 4.4 \\
\hline textbook use for & Ease of Use & 4.6 \\
\cline { 2 - 3 } learning & Self-Confidence Using & 4.8 \\
\cline { 2 - 3 } & Satisfaction Of Use & 4.2 \\
\hline Textbook Object & Textbook Suitability with & 4.4 \\
& Material & \\
\hline
\end{tabular}

\section{CONCLUSION}

Based on the results of the research that has been carried out, it shows that the development of textbooks based on multiple intelligence is declared valid and practical.

\section{ACKNOWLEDGEMENTS}

The author would like to thank DRPM-Dikti Kemendikbud, through Lembaga Layanan Pendidikan Tinggi (LLDIKTI) I North Sumatra, who fully funded this research. The Beginner Lecturer Research Scheme Grant Program really helps us as young lecturers to develop our competences.

\section{REFERENCES}

Abdullah, I. H. (2012). Peningkatan Kemampuan Representasi Matematis Siswa Smp Melalui Pembelajaran Kontekstual. Prosiding, November, 978-979.

Andayani Mirda, T., Adlim, A., \& Mursal, M. (2018). Pengembangan Lembar Kerja Peserta Didik Berbasis Multiple Intelligences Pada Materi Gerak Harmonik. Jurnal Pendidikan Sains Indonesia, 5(2), 95-103.

https:// doi.org/10.24815/jpsi.v5i2.9823

Anggela, M., Masril, \& Darvina, Y. (2013). Pengembangan Buku Ajar Bermuatan Nilai-Nilai Karakter pada Materi Usaha dan Momentum untuk Pembelajaran Fisika Siswa Kelas XI SMA. Pillar of Physics Education, 1(1), 63-70.

https:// doi.org/http://dx.doi.org/10.24036/492171074

Aradea, R., \& Harapan, E. (2019). Pengaruh Penerapan Teori Belajar Humanistik Terhadap Hasil Belajar Mahasiswa Pada Mata Kuliah Kewirausahaan. JMKSP (Jurnal Manajemen, Kepemimpinan, Dan Supervisi Pendidikan), 4(1), 90.

https:// doi.org/10.31851/jmksp.v4i1.2479

Budiningsih, T. Y., Rusilowati, A., \& Marwoto, P. (2015). Pengembangan Buku Ajar Ipa Terpadu Berorientasi Literasi Sains Materi Energi Dan Suhu. Journal of Innovative Science Education, 4(2), 34-40.

https:// doi.org/10.8366/Jinse.v5.i2.9902
Darmadi, H. (2012). Kemampuan Dasar mengajar (Landasan Konsep dan Implementasi). Alfabeta.

Fitriani, K., \& Maulana, (2016). Meningkatkan Kemampuan Pemahaman Dan Pemecahan Masalah Matematis Siswa Sd Kelas V Melalui Pendekatan Matematika Realistik. Mimbar Sekolah Dasar, 3(1), 40-52. https://doi.org/10.17509/mimbarsd.v3i1.2355

Fonna, M., \& Mursalin, M. (2019). Using of wingeom software in geometry learning to improving the of mathematical representation ability. Malikussaleh Journal of Mathematics Learning (MJML), 1(2), 40-43.

Gazali, R. Y. (2016). Pengembangan Bahan Ajar Matematika untuk Siswa SMP Berdasarkan Teori Belajar Ausubel Development of Mathematics Teaching Material for Junior High School Students Based on Ausubel Learning Theory. Pythagoras: Jurnal Pendidikan Matematika, 11(2), 182-192.

https://doi.org/http://dx.doi.org/10.21831/pg.v11i2.10644

Graciella, M., \& Suwangsih, E. (2016). Penerapan Pendekatan Matematika Realistik Untuk Meningkatkan Kemampuan Representasi Matematis Siswa. Metodik Didaktik, 10(2), 27-36. https://doi.org/10.17509/md.v10i2.3180

Husamah, Pantiwati, Y., Restian, A., \& Sumarsono, P. (2557). Belajar dan Pembelajaran (Vol. 7, Issue 2). Universitas Muhammadiyah Malang Pess.

Ilyas, S. N. (2019). Aplikasi Multiple Intelligences System (MIS) dalam Pembelajaran Anak Usia Dini Studi Kasus di Rumah Sekolah Cendekia Makassar. PAUDIA: Jurnal Penelitian Dalam Bidang Pendidikan Anak Usia Dini, 8(2), 50-56. https://doi.org/10.26877/paudia.v8i2.4882

Irsalina, A., \& Dwiningsih, K. (2018). Practicality Analysis of Developing the Student Worksheet Oriented Blended Learning in Acid Base Material. JKPK (Jurnal Kimia Dan Pendidikan Kimia), 3(3), 171.

https://doi.org/10.20961/jkpk.v3i3.25648

Jailani, M. sahran. (2017). Pengembangan Sumber Belajar Berbasis Karakter Peserta Didik (Ikhtiar optimalisasi Proses Pembelajaran Pendidi-kan Agama Islam (PAI)). Nadwa, 10(2), 175. https://doi.org/10.21580/nw.2016.10.2.1284

Jasmine, J. (2007). Panduan Praktis Mengajar Berbasis Multiple Intelligences. Nuansa.

Jumiati, Y., \& Zanthy, L. S. (2020). Analisis kesalahan siswa dalam menyelesaikan soal cerita persamaan dan pertidaksamaan linear satu variabel. JPMI: Jurnal Pembelajaran Matematika Inovatif, 3(1), 11-18. https://doi.org/10.22460/jpmi.v3i1.p1118

Kandeel, R. A. A. (2016). Multiple Intelligences Patterns among Students at King Saud University and Its Relationship with Mathematics' Achievement. Journal of Education and Learning, 5(3), 94. https://doi.org/10.5539/jel.v5n3p94

Kemendikbud. (2013). Buku Guru Matematika. Pusat Perbukuan Kemendikbud.

Kusniawati, E. (2016). Pembelajaran Berbasis Multiple Intelligences. NUANSA: Jurnal Studi Islam Dan Kemasyarakatan, 9(2), 167177. https://doi.org/10.24042/terampil.v6i2.5180

Latifah, U. H., \& Widjajanti, D. B. (2017). Pengembangan bahan ajar statistika dan peluang berbasis multiple intelligences berorientasi pada prestasi, pemecahan masalah, dan rasa ingin tahu. Jurnal Riset Pendidikan Matematika, 4(2), 176. https:// doi.org/10.21831/jrpm.v4i2.13083 
Lestari, I. (2018). Pengembangan Bahan Ajar Matematika dengan Memanfaatkan Geogebra untuk Meningkatkan Pemahaman Konsep. GAUSS: Jurnal Pendidikan Matematika, 1(1), 26. https://doi.org/10.30656/gauss.v1i1.634

Machali, I. (2014). Dimensi Kecerdasan Majemuk dalam Kurikulum 2013. Insania: Jurnal Pemikiran Alternatif Kependidikan, 19(1), 21-45. https://doi.org/10.24090/insania.v19i1.462

Majid, A. (2011). Perencanaan Pembelajaran Mengembangkan Standar Kompetensi Guru. Remaja Rosdakarya.

Maulidawati, M., Muhammad, I., Rohantizani, R., \& Mursalin, M. (2020). The Implementation of Make a Match Type Cooperative Learning Model to Improve the Mathematical Connection Ability. International Journal for Educational and Vocational Studies, 2(11).

Murdiyani, I. (2012). Pembelajaran Biologi Menggunakan Metode ELearning Berbasis Multiple Intelligences Pada Materi Sistem Gerak Manusia. Innovative Journal of Curriculum and Educational Technology, 1(1). https:// doi.org/10.15294/IJCET.V1I1.130

Muslimin, Putri, R. I. I., \& Somakin. (2012). Desain Pembelajaran Pengurangan Bilangan Bulat Melalui Permainan Tradisional Congklak Berbasis Pendidikan Matematika Realistik Indonesia di Kelas IV Sekolah Dasar. Kreano: Jurnal Matematika Kreatif-Inovatif, 3(2), 100-112.

https://doi.org/10.15294/ kreano.v3i2.2642

Nafii, A. Y. (2017). Pemahaman Siswa SMP terhadap Konsep Persamaan Linear Satu Variabel (PLSV) Ditinjau dari Perbedaan Jenis Kelamin. Kreano, Jurnal Matematika KreatifInovatif, 8(2), 119-125.

https://doi.org/10.15294/kreano.v8i2.10259

NCTM. (2000). Principles standards and for school mathematics. The National Council of Teachers of Mathematics, Inc.

Ningtyas, R., Yunianta, T. N. H., \& Wahyudi, W. (2014). Pengembangan Handout Pembelajaran Tematik Untuk Siswa Sekolah Dasar Kelas Iii. Scholaria: Jurnal Pendidikan Dan Kebudayaan, 4(3), 42.

https:// doi.org/10.24246/j.scholaria.2014.v4.i3.p42-53

Nurmita, F. (2017). Pengembangan Buku Ajar Siswa dan Buku Guru Berbasis Matematika Realistik untuk Meningkatkan Pengetahuan, Sikap dan Keterampilan Matematika Siswa Kelas VII SMP Al-Karim Kota Bengkulu. EDU-MAT Jurnal Pendidikan Matematika, 5(1), 86-98.

https:// doi.org/http://dx.doi.org/10.20527/edumat.v5i1.38 25

Paroqi, L. L., Mursalin, M., \& Marhami, M. (2020). The Implementation of Realistic Mathematics Education Approach to Improve Students' Mathematical Communication Ability in Statistics Course. International Journal for Educational and Vocational Studies, 2(10).

Perni, N. N. (2019). Penerapan Teori Belajar Humanistik Dalam Pembelajaran. Adi Widya: Jurnal Pendidikan Dasar, 3(2), 105. https://doi.org/10.25078/aw.v3i2.889

Prasetyo, W. (2012). Pengembangan lembar kegiatan siswa (LKS) dengan pendekatan pmr pada materi lingkaran di kelas VIII SMPN 2 Kepohbaru Bojonegoro. Mathedunesa, 1(1). https://jurnalmahasiswa.unesa.ac.id/index.php/mathedune sa/article/view/246

Putriani, D., \& Rahayu, C. (2018). The effect of discovery learning model using sunflowers in circles on mathematics learning outcomes. International Journal of Trends in Mathematics Education Research, 1(1), 22-25.

Qodir, A. (2017). Teori Belajar Humanistik Dalam Meningkatkan Prestasi Belajar Siswa. Jurnal Pedagogik, 04(02), 193-194. https://doi.org/https://doi.org/10.33650/pjp.v4i2.17

Rofiah, N. H. (2016). Menerapkan multiple intelligences dalam pembelajaran di sekolah dasar. Jurnal Dinamika Pendidikan Dasar, 8(1), 69-79.

https:// doi.org/10.30595/dinamika.v8i1.937

Ridhollah, M., Muliana, M., \& Mursalin, M. (2021). The Influence of Cooperative Integrated Reading and Composition Model on Completing Abilities of Story Questions. Malikussaleh Social and Political Reviews, 2(1), 33-42.

Sadjati, I. M. (2012). Pengembangan Bahan Ajar. In Pengembangan Bahan Ajar (pp. 1-62). Universitas Terbuka. https:// doi.org/10.1017/CBO9781107415324.004

Sajadi, M., Amiripour, P., \& Rostamy-Malkhalifeh, M. (2013). The Examinig Mathematical Word Problems Solving Ability under Efficient Representation Aspect. Mathematics Education Trends and Research, 2013, 1-11.

https:// doi.org/10.5899/2013/metr-00007

Sarah, K., Mursalin, M., Muliana, M., Nuraina, N., \& Rohantizani, R. (2021). The Influence of the Inside Outside Circle Cooperative Learning Model on Students' Mathematical Communication Ability. International Journal for Educational and Vocational Studies, 3(3), 177-185.

Samsuriadi, S., \& Imron, M. A. (2019). The Effect of Think Pair Share (TPS) Learning Model with Problem Solving Approach on the Student's Math Communication in MA DA Jarowaru. Malikussaleh Journal of Mathematics Learning (MJML), 2(1), 9-12.

Şener, S., \& Çokçalışkan, A. (2018). An Investigation between Multiple Intelligences and Learning Styles. Journal of $\begin{array}{llll}\text { Education and Training Studies, 6(2), } 125 & \end{array}$ https:// doi.org/10.11114/jets.v6i2.2643

Setiawan, A. R. (2019). Literasi Saintifik Berdasarkan Kecerdasan Majemuk dan Motivasi Belajar. Jurnal Penelitian Dalam Bidang Pendidikan Dan Pengajaran, 13(2), 126-137.

https://doi.org/http://dx.doi.org/10.26877/mpp.v13i2.4913

Sholeh, K. (2013). Pengembangan Teks Materi Pembelajaran Bahasa Indonesia dalam Buku Ajar Berbasis Multiple Intelligences dalam Kurikulum 2013. Seminar Nasional Pendidikan Bahasa Indonesia 2013, 2, 144-161.

https://doi.org/hdl.handle.net/11617/3356

Soeyono, Y. (2014). Pengembangan Bahan Ajar Matematika dengan Pendekatan Open-ended untuk Meningkatkan Kemampuan Berpikir Kritis dan Kreatif Siswa SMA. Pythagoras: Jurnal Pendidikan Matematika, 9(2), 205-218. https:// doi.org/10.21831/pg.v9i2.9081

Su'udiah, F., Degeng, I., \& Kuswandi, D. (2016). Pengembangan Buku Teks Tematik Berbasis Kontekstual. Jurnal Pendidikan: Teori, Penelitian, Dan Pengembangan, 1(9), 1744-1748-1748. https://doi.org/10.17977/jp.v1i9.6743

Sujarwo, S., \& Oktaviana, R. (2017). Pengaruh Warna Terhadap Short Term Memory Pada Siswa Kelas Viii Smp N 37 Palembang. Psikis: Jurnal Psikologi Islami, 3(1), 33. https:// doi.org/10.19109/psikis.v3i1.1391

Sukerni, P. (2014). Pengembangan Buku Ajar Pendidikan Ipa Kelas Iv Semester I Sd No. 4 Kaliuntu Dengan Model Dick and Carey. IPI (Jurnal Pendidikan Indonesia), 3(1), 386-396. https://doi.org/10.23887/jpi-undiksha.v3i1.2920 
Sulastri, S., Marwan, M., \& Duskri, M. (2017). Kemampuan Representasi Matematis Siswa SMP Melalui Pendekatan Pendidikan Matematika Realistik. Beta Jurnal Tadris Matematika, 10(1), 51.

https:// doi.org/10.20414/ betajtm.v10i1.101

Suwanto. (2018). Peningkatan Kemampuan Representasi Matematis Siswa melalui Pembelajaran Kooperatif Berbasis Multiple Intelligence di Kelas VIII SMP Budisatrya Medan. MAIKA (Majalah Ilmiah Kaputama), 2(2), 27-34.

https:// doi.org/10.84927/Kaputama.v2.i2.249

Suwarni, E. (2015). Pengembangan Buku Ajar Berbasis Lokal Materi Keanekaragaman Laba-Laba Di Kota Metro Sebagai Sumber Belajar Alternatif Biologi Untuk Siswa Sma Kelas X. BIOEDUKASI (Jurnal Pendidikan Biologi), 6(2), 86-92. https:// doi.org/10.24127/ bioedukasi.v6i2.336

Tasari, T. D. (2011). Matematika untuk SMP dan MTs Kelas VII. Pusat Kurikulum dan Perbukuan Kemendikbud.

Usmadi, U., Hasanah, H., \& Ergusni, E. (2020). The impact of the implementation three-step Interview cooperative learning model in mathematics learning toward the learners' activities and outcomes. Malikussaleh Journal of Mathematics Learning (MJML), 3(1), 8-12.

Wagiyo, A., Surati, F., \& Supradiarini, I. (2008). Buku Pegangan Belajar Matematika. Pusat Kurikulum dan Perbukuan Kemendikbud.

Yaumi, M. (2012). Pembelajaran Berbasis Multiple Intelligences. Dian Rakyat.

Yarmasi, Y., Fonna, M., \& Mursalin, M. (2020). The Influence of Cooperative Learning Model Type Team Assisted Individualized of Interactive Media Assistance to Students' Mathematical Communication Ability. International Journal for Educational and Vocational Studies, 2(9).

Yazid, A. (2012). Pengembangan Perangkat Pembelajaran Matematika Model Kooperatif Dengan Strategi Ttw (ThinkTalk- Write) Pada Materi Volume Bangun Ruang Sisi Datar. Journal of Primary Education, 1(1).

https:// doi.org/10.15294/jpe.v1i1.52

Yuniawatika. (2011). Penerapan Pembelajaran Mateamtika dengan Strategi REACT untuk Meningkatkan Kemampuan Koneksi dan Representasi Matematis Siswa Sekolah Dasar (Studi Kuasi Eksperimen di Kelas V Sekolah Dasar Kota Cimahi). In A. Nurjaman, R. Sariningsih, \& F. Ardiansyah (Eds.), Prospoding Seminar Nasional Pendidikan Matematika (Vol. 1, pp. 97-105). https://doi.org/10.17509/eh.v4i2.2830 